\title{
Pembelajaran Matematika dengan Pendekatan Cooperative Learning Ditinjau dari Prestasi Belajar, Motivasi, dan Akhlak Mulia Siswa
}

\section{Lella Tahlilla Yasna}

MA Ali Maksum Krapyak Yogyakarta. Jalan Kyai Haji Ali Maksum RT. 5, Dusun Krapyak Kulon, Desa Panggungharjo, Kec. Sewon, Bantul, Daerah Istimewa Yogyakarta, Indonesia.

Korespondensi Penulis. Email: lty.lella@gmail.com, Telp: +6281340081766

Received: 15 ${ }^{\text {th }}$ June 2016; Revised: $29^{\text {th }}$ August 2016; Accepted: $1^{\text {st }}$ September 2016

\begin{abstract}
Abstrak
Penelitian ini bertujuan untuk mendeskripsikan keefektifan pembelajaran matematika dengan pendekatan cooperative learning tipe Student Teams-Achievement Divisions (STAD) dan cooperative learning tipe Jigsaw serta membandingkan keefektifan kedua pendekatan tersebut ditinjau dari prestasi, motivasi belajar, dan akhlak mulia siswa. Jenis penelitian ini adalah quasi experiment dengan pretest-posttest nonequivalent group design. Populasi dalam penelitian ini adalah siswa kelas X MA Ali Maksum, sedangkan sampel dalam penelitian ini adalah siswa kelas X-E dan X-G. Untuk menguji keefektifan pembelajaran matematika dengan pendekatan cooperative learning tipe STAD dan cooperative learning tipe Jigsaw ditinjau dari masing-masing variabel, data dianalisis menggunakan uji $t$-test one sample, sedangkan untuk membandingkan keefektifan pembelajaran menggunakan kedua pendekatan tersebut, data dianalisis secara multivariat dengan statistik uji two-group MANOVA. Hasil penelitian menunjukkan bahwa pendekatan cooperative learning tipe STAD dan tipe Jigsaw efektif digunakan dalam pembelajaran matematika dan tidak terdapat perbedaan keefektifan penggunaan kedua pendekatan tersebut dalam pembelajaran matematika ditinjau dari prestasi, motivasi belajar, dan akhlak mulia siswa.
\end{abstract}

Kata kunci: cooperative learning tipe STAD, cooperative learning tipe jigsaw, prestasi belajar, motivasi belajar, dan akhlak mulia

\section{Learning Mathematics with Cooperative Learning Approach in Terms of Students' Achievement, Motivation, and Noble Character}

\begin{abstract}
This study aimed to describe the effectiveness of mathematics learning using cooperative learning approach type Student Teams-Achievement Divisions (STAD) and cooperative learning type Jigsaw and to compare the effectiveness of both approaches in terms of students' achievement, learning motivation, and noble character. This study was a quasi experiment research with pretestposttest nonequivalent group design. The study population included all students of class X MA Ali Maksum and the sample was class $X-E$ and $X-G$ that were selected randomly. To determine the effectiveness of mathematics learning using cooperative learning approach type STAD and cooperative learning type Jigsaw in terms of each variables, the data were analyzed using one sample t-test. Then to compare the effectiveness of mathematics learning using both approaches, the data were analyzed using multivariate statistical with two-group MANOVA test. The results show that the mathematics learning with cooperative learning type STAD and jigsaw was effective and there is no difference in the effectiveness of mathematics learning using cooperative learning type STAD and jigsaw in terms of students' achievement, learning motivation, and noble character.
\end{abstract}

Keywords: cooperative learning type STAD, cooperative learning type jigsaw, learning achievement, learning motivation, and noble character.

How to Cite: Yasna, L. (2016). Pembelajaran matematika dengan pendekatan cooperative learning ditinjau dari prestasi belajar, motivasi, dan akhlak mulia siswa. PYTHAGORAS: Jurnal Pendidikan Matematika, 11(1), 45-58. doi:http://dx.doi.org/10.21831/pg.v11i1.9676

Permalink/ DOI: http://dx.doi.org/10.21831/pg.v11i1.9676 


\section{PENDAHULUAN}

Ilmu dan pendidikan mempunyai kedudukan yang tinggi dalam pandangan Islam. Pendidikan sangat penting bagi kehidupan manusia dan lingkungan sekitarnya, karena pendidikanlah yang membedakan manusia dengan makhluk lain. Pendidikan juga menempati posisi penentu dalam rentang peradaban manusia. Di Indonesia, pendidikan diatur dalam UUD 1945 khususnya pasal 31. Selain dalam UUD 1945, pendidikan juga diatur dalam Undang-undang Nomor 20 Tahun 2003 tentang Sistem Pendidikan Nasional. Dalam undangundang tersebut, dijabarkan bahwa pendidikan merupakan usaha sadar dan terencana untuk mewujudkan suasana belajar dan proses pembelajaran agar peserta didik secara aktif mengembangkan potensi dirinya untuk memiliki kekuatan spiritual keagamaan, pengendalian diri, kepribadian, kecerdasan, akhlak mulia, serta keterampilan yang diperlukan dirinya, masyarakat, bangsa, dan negara. Mendukung hal tersebut, dalam Peraturan Pemerintah Nomor 19 tahun 2005 tentang Standar Nasional Pendidikan pasal 26 ayat 2 disebutkan bahwa standar kompetensi lulusan pada satuan pendidikan menengah umum bertujuan untuk meningkatkan kecerdasan, pengetahuan, kepribadian, akhlak mulia, serta keterampilan untuk hidup mandiri dan mengikuti pendidikan lebih lanjut. Bila mengacu pada fungsi dan tujuan pendidikan nasional tersebut, jelas bahwa pengembangan nilai-nilai agama dan akhlak mulia menjadi hal yang sangat penting dalam proses pendidikan.

Sementera itu, sistem pendidikan di Indonesia telah mengisyaratkan bahwa pembelajaran seharusnya menyeimbangkan aspek kognitif, afektif, dan psikomotor. Senada dengan pernyataan tersebut, Cohen (2006, p.210) mengemukakan bahwa "goal of education need to be reframe to prioritize not only academic learning but also social, emotional and ethnical competencies". Hal tersebut menurut Cohen (2006, p.210) sangat penting karena "education can help children reach the goal their parents and teachers have for them: learning to 'read' themselves and other, learning to solve social, emotional and ethnical problem". Akan tetapi sangat disayangkan bahwa pendidikan di Indonesia dinilai terlalu menonjolkan kognisi tetapi minus emosi dan moral. Sebagian pemerhati pendidikan bahkan menilai bahwa pendidikan kita terkesan mekanistik, full hafalan, dan mematikan kreativitas siswa (Musfiroh, 2008, p.25). Dalam kegiatan pendidikan, proses pemaknaan terhadap materi yang diajarkan dan metode pembelajaran tidak dianggap penting. Hal tersebut mengakibatkan proses pendidikan yang tidak menyentuh ke dasar hati, sehingga tidak memberikan pengalaman-pengalaman secara kontekstual yang menumbuhkan kesadaran nilai.

Melihat proses pendidikan yang sedemikian rupa, tidak mengherankan bila hasil dari proses pendidikan anak bangsa sangat memprihatinkan dan semakin jauh dari nilai-nilai moral dan akhlak mulia. Data-data yang diperoleh peneliti menyebutkan bahwa hasil survei BNN sejak tahun 2009, prevalensi penyalahgunaan narkoba pada tahun 2009 adalah 1,99\% dari penduduk Indonesia yang berumur 10-59 tahun atau sekitar 3,6 juta orang. Pada tahun 2010, prevalensi penyalahgunaan narkoba meningkat menjadi 2,21\% atau sekitar 4,02 juta orang. Pada tahun 2011, prevalensi penyalahgunaan meningkat menjadi $2,8 \%$ atau sekitar 5 juta orang. Kalangan yang paling rentan dalam rentang umur tersebut adalah kalangan pelajar (Kompas, 2011). Selain penggunaan narkoba, masih terdapat banyak penyimpangan terhadap nilai-nilai moral dan akhlak mulia yang dilakukan oleh siswa sekolah, seperti tawuran, pergaulan bebas, tindak asusila, bahkan kriminalitas. Senada dengan hal tersebut, Lickona (1991, pp.13-18) mengungkapkan bahwa terdapat sepuluh tanda-tanda zaman yang harus diwaspadai, karena bila tanda-tanda ini sudah ada, hal tersebut menandakan bahwa sebuah bangsa sedang menuju jurang kehancuran. Kesepuluh tanda-tanda yang dimaksud adalah (1) meningkatnya kekerasan dikalangan remaja, (2) pengunaan bahasa dan kata-kata yang memburuk, (3) pengaruh peer-group yang kuat dalam tindak kekerasan, (4) meningkatnya perilaku merusak diri, seperti penggunaan narkoba, alkohol, dan seks bebas, (5) semakin kaburnya pedoman moral baik dan buruk, (6) menurunnya etos kerja, (7) semakin rendahnya rasa hormat kepada orang tua dan guru, (8) rendahnya rasa tanggung jawab individu dan warga negara, (9) membudayanya ketidakjujuran, dan (10) adanya saling curiga dan kebencian di antara sesama.

Sementara itu, salah satu peran guru adalah sebagai motivator. Dalam pembelajaran, motivasi sangat dibutuhkan untuk meningkatkan kegairahan belajar siswa. Seperti yang disebutkan pada Permendiknas Nomor 41 Tahun 2007 tentang Standar Proses, bahwa proses pembelajaran dirancang dengan berpusat pada peserta didik untuk mendorong motivasi, minat krea- 
tivitas, inisiatif, inspirasi, kemandirian dan semangat belajar. Sardiman (2011, p.145) memandang bahwa motivasi dapat merangsang dan mendorong serta reinforcement untuk mendinamisasikan potensi siswa, menumbuhkan aktivitas dan kreativitas siswa, sehingga terjadi dinamika dalam proses pembelajaran. Sebagai tenaga pendidik, dalam kegiatan pembelajaran guru memiliki tujuan utama untuk menciptakan suasana belajar yang menyenangkan, dapat menarik minat dan antusias siswa serta dapat memotivasi siswa untuk senantiasa belajar dengan baik dan semangat, sebab dengan suasana belajar yang menyenangkan akan berdampak positif dalam pencapaian prestasi belajar yang optimal. Prestasi belajar siswa merupakan suatu indikasi dari perubahan-perubahan yang terjadi pada diri siswa setelah mengalami proses belajar mengajar. Dari prestasi inilah dapat dilihat keberhasilan siswa dalam memahami suatu materi pelajaran, tak terkecuali pelajaran matematika.

Dalam pembelajaran matematika di MA Ali Maksum, siswa masih mengalami kesulitan pada beberapa materi, salah satunya pada materi perbandingan trigonometri. Kesulitan siswa pada materi tersebut umumnya terletak pada penguasaan konsep dasar yang dimiliki. Hal tersebut yang menyebabkan siswa kesulitan untuk menentukan nilai perbandingan trigonometri. Motivasi belajar dan tanggung jawab yang kurang, menyebabkan juga prestasi belajar matematika pada materi trigonometri yang masih rendah. Pada tahun pelajaran 2010/2011, nilai rata-rata ulangan harian dari 219 siswa untuk pokok bahasan trigonometri adalah 57 . Rendahnya prestasi belajar siswa dalam materi trigonometri juga terlihat dari daya serap siswa tahun pelajaran 2008/2009 dan tahun pelajaran 2009/2010 yang cenderung menurun.

Pada Tabel 1 terlihat bahwa terdapat penurunan daya serap pada soal-soal trigonometri dalam 5 tahun terakhir. Bahkan pada tahun pelajaran 2009/2010, daya serap siswa untuk menyelesaikan persamaan trigonometri dalam interval tertentu yang terdapat pada soal paket B sebesar $0,00 \%$. Berdasarkan data tersebut, agar pembelajaran matematika dapat diserap secara baik oleh siswa, diperlukan suatu pendekatan pembelajaran yang dipandang tepat. Pendekatan pembelajaran yang dirasa dapat meningkatkan motivasi belajar dan akhlak mulia siswa, sehingga dapat juga meningkatkan prestasi belajarnya.

Dalam penelitian ini, peneliti memilih pendekatan pembelajaran cooperative learning tipe STAD dan cooperative learning tipe jigsaw yang dirancang untuk mempengaruhi pola interaksi siswa dan melibatkan lebih banyak siswa dalam menelaah materi yang tercakup dalam suatu pelajaran. STAD merupakan salah satu tipe pembelajaran kooperatif yang paling sederhana, dan merupakan pendekatan yang paling baik untuk permulaan bagi para guru yang baru menggunakan pendekatan kooperatif.

Hasil penelitian yang dikutip oleh Slavin (2008, p.133) mengungkapkan bahwa ketertarikan terhadap kelas yang diajarkan dengan pendekatan cooperative learning tipe jigsaw lebih besar daripada kelas-kelas kontrol yang tidak menggunakan cooperative learning. Selanjutnya kajian lain yang dikutip Slavin (2008, p.35) menyatakan bahwa di dalam kelas yang menggunakan cooperative learning, para siswa berusaha keras untuk selalu hadir di kelas. Mereka juga tidak segan untuk membantu siswa lainnya untuk belajar, dipuji, dan didukung oleh teman satu timnya. Hal ini dapat memotivasi siswa untuk belajar dan mencapai prestasi yang lebih tinggi. Hasil penelitian tesebut menunjukkan bahwa pendekatan cooperative learning tipe jigsaw merupakan pendekatan pembelajaran yang efektif untuk meningkatkan partisipasi siswa, ketertarikan siswa terhadap matematika dan pelajaran matematika bahkan meningkatkan prestasi belajar siswa. Hal ini diperkuat oleh hasil penelitian Suratno (2014) yang menunjuk-kan bahwa pembelajaran matematika dengan menggunakan pembelajaran kooperatif efektif ditinjau dari prestasi belajar dan karakter siswa. Partisipasi dan kesenangan siswa terhadap matematika dan belajar matematika akan memberikan efek yang positif terhadap pembentukan akhlak mulia dan pencapaian prestasi belajar siswa. 
Tabel 1. Persentase Daya Serap Materi Trigonometri Siswa MA Ali Maksum pada UN

\begin{tabular}{|c|c|c|c|c|c|c|}
\hline \multirow{3}{*}{ Kemampuan yang diuji } & \multicolumn{5}{|c|}{ Ujian Nasional } & \multirow{3}{*}{2011} \\
\hline & \multirow{2}{*}{2007} & \multirow{2}{*}{2008} & \multirow{2}{*}{2009} & \multicolumn{2}{|c|}{2010} & \\
\hline & & & & $\mathbf{A}$ & $\mathbf{B}$ & \\
\hline $\begin{array}{l}\text { Menyelesaikan soal cerita yang menggunakan perbandingan } \\
\text { trigonometri }\end{array}$ & 73,68 & 27,28 & - & - & - & - \\
\hline $\begin{array}{l}\text { Menentukan himpunan penyelesaian dari persamaan } \\
\text { trigonometri }\end{array}$ & - & 13,64 & 86,84 & - & - & 28,95 \\
\hline Menentukan nilai perbandingan trigonometri dengan & - & 43,18 & 71,06 & 26,32 & 5,26 & 15,79 \\
\hline menggunakan jumlah dan selisih sinus, kosinus, dan tangen & & 70,46 & 81,58 & 73,68 & 15,79 & 36,84 \\
\hline Menyelesaikan persamaan trigonometri dalam interval tertentu & - & - & - & 31,58 & 0,00 & - \\
\hline
\end{tabular}

(Sumber: BSNP)

Fakta ini didukung oleh teori belajar konstruktivis yang dikemukakan oleh Arends (2008, p.9) bahwa pendekatan cooperative learning membawa keuntungan akademis maupun sosial bagi siswa. Mempertegas pendapat tersebut, Dewey 8 Thelen (Arends, 2008, p.7) menyatakan bahwa perilaku kooperatif sebagai pondasi demokrasi dan sekolah sebagai laboratorium dan miniatur demokrasi bertujuan mempelajari, menyelidiki berbagai masalah sosial dan interpersonal. Lingkungan sekolah yang demokratis memungkinkan siswa untuk bertanggung jawab atas kesuksesan belajar secara individual dan secara bersama-sama. Kenyataan menunjukkan bahwa siswa yang diajarkan dalam lingkungan kelas yang demokratis akan jauh lebih bertahan karena memiliki motivasi yang tinggi untuk tetap pada tugas-tugas akademiknya.

Dukungan teori motivasi juga menyatakan bahwa pembelajaran kooperatif difokuskan pada tujuan penghargaan dimana siswa bekerja. Duetch (Slavin, 2008, p.34) menyatakan bahwa usaha yang berorientasi tujuan dari tiap individu, memberi kontribusi pada pencapaian tujuan individu lain, sedangkan ada pembelajaran yang kompetitif usaha tiap individu yang berorientasi tujuan akan menghalangi pencapaian tujuan anggota yang lain, sedangkan pencapaian tujuan pada prinsip individualistik tidak memiliki konsekuensi terhadap pencapaian tujuan individu lain. Hal ini menunjukkan bahwa struktur tujuan pembelajaran kooperatif menciptakan sebuah situasi dimana satu-satunya cara anggota kelompok mencapai tujuan adalah jika kelompok mereka berhasil.

Slavin (2005, p.122) menyatakan bahwa dalam jigsaw para siswa bekerja dalam tim yang heterogen. Para siswa tersebut diberikan tugas untuk membaca beberapa bab atau unit dan diberikan lembar ahli yang terdiri atas topik-topik berbeda yang harus menjadi fokus perhatian masing-masing anggota tim saat mereka membaca.
Setelah semua siswa selesai membaca, siswasiswa dari tim yang berbeda yang mempunyai fokus topik yang sama bertemu dalam kelompok ahli untuk mendiskusikan topik mereka sekitar 30 menit. Para ahli tersebut kemudian kembali kepada tim mereka dan secara bergantian mengajari teman satu timnya mengenai topik mereka. Yang terakhir adalah para siswa menerima penilaian yang mencakup seluruh topik, dan skor kuis akan menjadi skor tim. Penskoran pada tipe jigsaw sama dengan penskoran pada tipe STAD. Menurut Borich (2007, p.389) kegiatan pembelajaran kooperatif yang disebut jigsaw dilaksanakan dengan cara guru menetapkan siswa untuk 4-6 anggota tim untuk bekerja pada tugas akademik dibagi menjadi beberapa subtugas, tergantung pada jumlah kelompok. Guru menetapkan kelompok siswa dan kemudian memberikan tanggung jawab kepada salah satu siswa untuk mengajar anggota kelompoknya.

Dijelaskan juga oleh Persky \& Pollack (2009, p.1) bahwa dalam pendekatan Jigsaw, peserta didik dibagi dalam kelompok-kelompok kecil dengan masing-masing anggota kelompok yang bertanggung jawab untuk mempelajari bagian dari keseluruhan teka-teki. Siswa kemudian belajar tentang bagian mereka, dan bersama bagian teta-teki yang mereka miliki, siswa tersebut bertemu dengan siswa yang lain yang memiliki bagian-bagian teka-teki yang lain. Lebih lanjut diuraikan, "The Jigsaw approach was used to provide students with individual accountability as they had to teach other members of their group what they learned while researching a problem". Pendekatan Jigsaw digunakan untuk memberikan para siswa akuntabilitas individu karena mereka harus mengajar anggota lain dari kelompok mereka apa yang mereka pelajari saat meneliti masalah.

Sementara Arends (1997, p.119) mengemukakan pendapat berkenaan dengan STAD bahwa "teacher employing STAD, also referred to as student team learning, present new 
academic information to student each week using verbal presentation or text". Berdasarkan pendapat tersebut dapat diketahui bahwa guru yang menggunakan STAD menyajikan informasi akademis baru kepada siswa setiap minggu atau secara reguler, baik melalui presentasi verbal atau tertulis. Borich (2007, p.388) menyatakan bahwa "in Student Team-Achievement Division (STAD), the teacher assigns students to four-or-five-members. Each team is as heterogeneous as possible to represent the composition of the enter class (boys/girls, higher achieving/ lower achieving, etc.)". Pernyataan tersebut bermakna bahwa dalam Student Team-Achievement Division (STAD), guru menetapkan siswa dalam tim yang terdiri atas empat sampai lima orang anggota. Komposisi setiap tim dalam kelas harus heterogen yang terdiri atas (laki-laki/perempuan, prestasi tinggi/prestasi rendah, dan lain-lain). Senada dengan pendapat tersebut, Arends \& Kilcher (2010, pp.317-318) menyatakan bahwa pembelajaran STAD melibatkan siswa untuk bekerja sama dalam kelompok-kelompok dan kelompok saling bersaing. Pendekatan ini telah cukup diteliti secara menyeluruh dan telah terbukti efektif untuk membantu siswa menguasai pengetahuan deklaratif berupa fakta-fakta dan informasi dasar konseptual. Selain itu, hasil penelitian Wahyuni \& Abadi (2014) juga menunjukkan bahwa pembelajaran STAD efektif diterapkan dalam pembelajaran matematika ditinjau dari ketercapaian kompetensi. Hal ini diperkuat dengan hasil penelitian Fahrurrozi \& Mahmudi (2014), bahwa pembelajaran STAD berpengaruh terhadap prestasi belajar matematika siswa.

Selanjutnya, kemampuan intelektual siswa sangat menentukan keberhasilan siswa dalam memperoleh prestasi. Untuk menentukan berhasil tidaknya seseorang dalam belajar maka dilakukan suatu evaluasi yang bertujuan untuk mengetahui hasil belajar yang diperoleh siswa setelah proses belajar mengajar berlangsung. Hasil belajar yang baik mencerminkan bukti belajar siswa. Winkel (1996, p.226) mengemukakan bahwa prestasi belajar merupakan bukti keberhasilan yang telah dicapai seseorang setelah melaksanakan usaha-usaha belajar.

Prestasi belajar merupakan hal yang tidak dapat dipisahkan dari kegiatan belajar, karena belajar merupakan proses, sedangkan prestasi merupakan hasil dari proses belajar. Johnson \& Johnson (2002, p.8) mendeskripsikan prestasi belajar, yaitu (1) prestasi berhubungan dengan perilaku (kemampuan berkomunikasi, melaksa- nakan aktivitas motorik tertentu, dan kemampuan memecahkan masalah yang kompleks); (2) prestasi yang berhubungan dengan produk (menulis laporan proyek, produk seni dan lain sebagainya), atau prestasi yang berhubungan dengan sikap dan watak (rasa bangga atas pekerjaan dan ingin meningkatkan kemampuan secara terus menerus, komitmen, manajemen diri, harga diri). Berdasarkan deskripsi tersebut, dapat dijelaskan bahwa prestasi belajar merupakan tingkat kemanusiaan (tingkah laku, hasil, sikap dan watak). Sementara itu, Urdan \& Maher (Tercanlioglu, 2004, p.35) menyatakan bahwa prestasi adalah salah satu teori motivasi yang merupakan gambaran dari tujuan siswa dalam pencapaian pembelajaran. Lussier \& Achua (Moore et al, 2010, p. 25) mengatakan bahwa prestasi belajar merupakan kebutuhan yang tidak tersadarkan, karena prestasi merupakan akibat dari usaha seseorang dalam mendapatkan sesuatu.

Menilai prestasi belajar dapat dilihat dari aspek kognitif siswa. Kemampuan berpikir dapat dinilai dan diukur melalui evaluasi dengan memperhatikan proses selama pembelajaran berlangsung. Kognitif mempunyai peran yang cukup penting terhadap pencapaian prestasi belajar siswa. Seperti diungkapkan Begle (1979, p.97) bahwa "... the best predictor of achievement at higher cognitive levels are previous mathematics achievement at higher cognitive levels". Dengan bekal kognitif yang dimiliki, kemampuan siswa akan menjadi lebih berkembang dengan adanya fasilitator dari guru. Sesuatu yang dianggap sulit dapat terselesaikan dengan adanya kerjasama yang baik antara siswa dan guru dalam pembelajaran. Arends \& Kiilcher (2010, p.59) menambahkan "achievement is satisfied when students strive to learn particular subjects or acquire difficult skills and are successful in their quest". Prestasi merupakan kepuasan tersendiri bagi siswa ketika berhasil mempelajari mata pelajaran tertentu atau mendapatkan keterampilan dalam menyelesaikan sesuatu yang dirasa sulit dan akhirnya berhasil dalam usahanya.

Prestasi belajar dapat diukur menggunakan alat ukur yang disebut tes hasil belajar. Tes hasil belajar terdiri atas kumpulan pertanyaan atau soal sebagai penjabaran dari materi yang telah dipelajari siswa. Masing-masing soal atau pertanyaan menggambarkan materi belajar sekaligus mencerminkan kompetensi dasar yang dituntut. Ebel \& Frisbie (1986, p.11) menyatakan "test provide the best information teachers 
and students ordinarily can get about the success of their effort to teach and learn". Tes merupakan informasi terbaik bagi guru maupun siswa mengenai kesuksesan dalam belajar dan mengajar. Sementara Romberg \& Shafer (2008, p.17) menyatakan bahwa pengukuran terhadap prestasi matematika baik dan sangat penting, akan tetapi untuk menilai prestasi tidak cukup diukur dari nilai yang standar saja. Artinya mengukur prestasi hasil belajar siswa merupakan unsur penting dalam hubungannya menghargai siswa, bukan semata karena nilai yang diperolehnya.

Selain prestasi, aspek lain yang penting dalam pembelajaran yaitu motivasi. Menurut Woodsworth (Sanjaya, 2008, p.250) "a motive is a set predisposes the individual of certain activities and for seeking certain goals". Motivasi adalah suatu yang membuat individuindividu melakukan berbagai kegiatan untuk mencapai tujuan. Lebih lanjut Sanjaya (2008, p.250) mempertegas bahwa perilaku atau tindakan-tindakan yang ditunjukkan oleh seseorang tergantung pada motif yang dimilikinya. Menurut Woolfolk (2004, p.372), "motivation is internal state that arouse, direct and maintains behaviour". Pernyataan tersebut bermakna bahwa motivasi merupakan suatu keadaan yang menggerakkan, mengarahkan dan mempertahankan perilaku. Robbins \& Judge (2009, p.209) mengatakan "motivation the processes that acount for an individual's intensity, direction, and persistence of effort toward attaining a goal'. Pendapat tersebut memiliki makna bahwa motivasi adalah proses menjelaskan intensitas, arah, dan ketekunan usaha untuk mencapai tujuan. Motivasi merupakan daya pendorong bagi individu melaksanakan aktivitas untuk mencapai tujuan tertentu. Kleinginna \& Kleinginna (Huit, 2001, p.198) menge-mukakan tentang definisi motivasi sebagai suatu keadaan internal/kondisi (kadang-kadang digambarkan sebagai sebuah kebutuhan, hasrat atau keinginan) untuk memulai suatu aktivitas atau kekuatan untuk bertindak secara langsung. Terdapat 3 hal penting dalam pengertian motivasi tersebut yaitu (1) keadaan internal atau kondisi yang menggerakkan perilaku dan dilakukan secara langsung, (2) hasrat atau keinginan dari kekuatan dan tujuan yang diorientasikan terhadap perilaku secara langsung, dan (3) berpengaruh terhadap kebutuhan dan hasrat atas intensitas secara langsung. Terkait dengan motivasi, Santrock (2008, p.510) mendifinisikan motivasi sebagai proses yang memberi semangat, arah, dan kegigihan perilaku. Artinya perilaku yang termotivasi adalah perilaku yang penuh energi, terarah dan bertahan lama.

Senada dengan pendapat tersebut, Schunk et al (2010, p.147) menyatakan bahwa "motivated learning is motivation to acquire skills and strategies rather than to perform tasks". Motivasi belajar adalah motivasi untuk memiliki keterampilan dan strategi bukannya untuk melaksanakan tugas-tugas. Middleton \& Spanias (Yunus \& Wan, 2009, p.93) mengemukakan bahwa "research indicates that success in mathematics is a powerful influence on the motivation to achieve". Pernyataan tersebut bermakna bahwa penelitian mengindikasikan bahwa keberhasilan dalam matematika sangat dipengaruhi oleh motivasi untuk mencapainya.

Selain prestasi dan motivasi, pembelajaran matematika juga harus berorientasi pada pembemtukan akhlak mulia. Ilyas (2006, p.2) mengemukakan bahwa akhlak adalah sifat yang tertanam dalam jiwa manusia sehingga muncul secara spontan bilamana diperlukan, serta tidak membutuhkan dorongan dari luar. Akhlak mulia dapat berupa sikap selalu menjaga kejujuran, tanggung jawab, disiplin, menghormati dan menghargai orang lain, senang membantu dan peduli pada orang lain, sikap rendah hati dan lain-lain. Senada dengan hal tersebut, Ismail Irianto (Zuriah, 2007, p.137) mengartikan akhlak sebagai tata nilai yang bersifat azali yang mewarnai cara berpikir, ber-sikap dan bertindak seseorang terhadap diri sendiri, Allah SWT dan Rasul-Nya, sesamanya serta lingkungan sekitarnya. Menurut Al-Qasimi (2000, p.204), hakekat akhlak adalah sesuatu yang tergores dalam jiwa yang mengeluarkan sesuatu perbuatan dengan mudah tanpa membutuhkan berpikir. Jika goresan tersebut mengeluarkan perbuatan yang bagus maka disebut akhlak mulia, dan jika mengeluarkan perbuatan yang jelek disebut akhlak yang jelek.

Berdasarkan uraian-uraian tersebut, maka yang menjadi tujuan dari penelitian ini adalah untuk mendeskripsikan keefektifan pembelajaran matematika dengan pendekatan cooperative learning tipe Student Teams-Achievement Divisions (STAD) dan cooperative learning tipe Jigsaw ditinjau dari prestasi belajar, motivasi belajar, dan akhlak mulia siswa dan membandingkan pembelajaran mana yang lebih efektif antara pendekatan cooperative learning tipe Student Teams-Achievement Divisions (STAD) dengan pendekatan cooperative learning tipe 
jigsaw ditinjau dari prestasi belajar, motivasi belajar, dan akhlak mulia siswa.

\section{METODE}

Jenis penelitian ini adalah penelitian eksperimen semu. Variabel terikat dalam penelitian ini yaitu prestasi belajar, motivasi belajar, dan akhlak mulia siswa, dengan variabel bebas pendekatan cooperative learning tipe jigsaw dan cooperative learning tipe STAD. Desain penelitian yang digunakan adalah Pretest-posttest nonekuivalenmultiple-group design dengan rancangan seperti disajikan pada Gambar 1.

Penelitian ini dilakukan di MA Ali Maksum, Ponpes Krapyak, Yogyakarta. Penelitian ini dilaksanakan pada semester genap tahun pelajaran 2011/2012 mulai bulan April 2012 sampai dengan bulan Juni 2012. Populasi penelitian adalah siswa kelas X MA Ali Maksum, semester genap tahun pelajaran 2011/2012. Jumlah siswa kelas X MA Ali Maksum, saat pelaksanaan penelitian adalah 162 siswa, tersebar dalam 6 rombongan belajar (kelas) paralel. Pengambilan sampel dilaksanakan dengan cara pengundian, yaitu dengan mengambil 2 kelas dari populasi yang terdiri atas 6 kelas yang siswanya terdistribusi secara merata untuk setiap kelas. Berdasarkan hasil pengundian, sampel yang diperoleh dan digunakan dalam penelitian ini adalah kelas X-E yang menerapkan pendekatan cooperative learning tipe jigsaw dan kelas X-G yang menerapkan pendekatan cooperative learning tipe STAD dengan membelajarkan materi pokok Trigonometri.

Teknik pengumpulan data yang digunakan dalam penelitian ini adalah teknik tes untuk megukur prestasi belajar siswa, dan nontes untuk mengukur motivasi belajar dan akhlak mulia siswa. Data dikumpulkan dengan teknik pretes dan postes. Tujuan pretes adalah untuk me-ngetahui kondisi awal siswa sebelum dilakukan perlakuan. Tujuan postes adalah untuk mengetahui prestasi belajar siswa setelah perlakuan.
Instrumen yang digunakan dalam penelitian ini adalah tes prestasi belajar matematika dan angket. Pengembangan instrumen dilakukan berdasarkan masukan dari pembimbing. Setelah instrumen disusun, kemudian divalidasi oleh tim ahli berdasarkan kesesuaian antara butir-butir pertanyaan dengan indikator masing-masing instrumen (validitas isi). Instrumen tes untuk mengukur prestasi belajar siswa, terdiri atas 30 butir soal pilihan ganda. Penyusunan tes diawali dengan pembuatan kisi-kisi soal dengan mengacu pada standar isi dalam Kurikulum Tingkat Satuan Pendidikan.

Sesuai dengan variabel dependen penelitian ini, maka instrumen untuk variabel motivasi belajar menggunakan instrumen nontes dalam bentuk angket. Angket berbentuk daftar cocok (cheklist) yang memuat pernyataan-pernyataan motivasi belajar matematika siswa. Model skala yang digunakan adalah skala likert dimana banyaknya skala yang digunakan adalah lima, dengan skor tertinggi 5 dan skor terendah 1. Kategori yang digunakan terdiri atas: selalu, sering, kadang-kadang, jarang, dan tidak pernah, dengan 30 butir item pernyataan motivasi belajar. Item tersebut diberikan kepada kelompok sebelum dan sesudah mengikuti pembelajaran dengan menggunakan pendekatan cooperative learning tipe STAD dan tipe Jigsaw.

Seperti halnya angket motivasi belajar, dalam angket akhlak mulia, model skala yang digunakan adalah skala likert dimana banyaknya skala yang digunakan adalah lima, dengan skor tertinggi 5 dan skor terendah 1. Kategori yang digunakan untuk dimensi keyakinan, terdiri atas sangat setuju, setuju, ragu-ragu, tidak setuju dan sangat tidak setuju. Sedangkan kategori yang digunakan untuk dimensi afeksi dan perilaku, terdiri atas selalu, sering, kadang-kadang, jarang, dan tidak pernah. Banyaknya item pernyataan akhlak mulia terdiri atas 60 butir. Item tersebut diberikan kepada kelompok sebelum dan sesudah mengikuti pembelajaran dengan menggunakan pendekatan cooperative learning tipe STAD dan tipe Jigsaw.

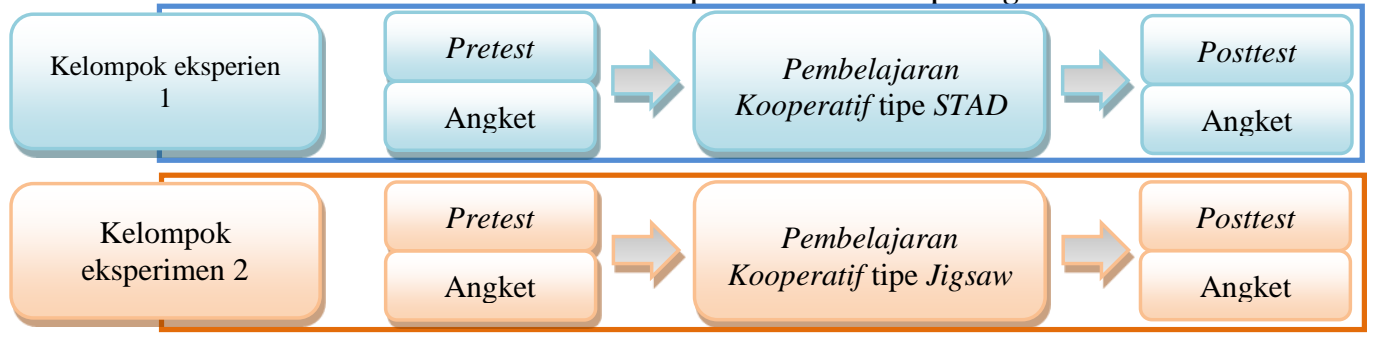

Gambar 1. Desain Penelitian (Pretest-postest non-ekuivalen multiple-group design) 
Untuk memperoleh bukti validitas isi dilakukan dengan cara meminta pertimbangan ahli (expert judgment) yang berkompeten di bidang yang bersangkutan. Validitas isi instrumen mengacu pada sejauh mana item instrumen mencakup keseluruhan situasi yang ingin diukur. Validitas isi instrumen tes dapat diketahui dari kesesuaian instrumen tes tersebut dengan SK dan KD. Sedangkan untuk angket motivasi belajar dan akhlak mulia siswa diketahui dari kesesuaian instrumen yang telah dikembangkan dengan kisi-kisinya. Selanjutnya berdasarkan masukan dari ketiga ahli tersebut, peneliti melakukan revisi instrumen.

Untuk mengestimasi koefisien relia-bilitas dari tes prestasi belajar digunakan formula Spearman-Brown dengan rumus sebagai berikut:

$r_{2}=\frac{2(r)}{r+1}$

Sedangkan untuk mengestimasi koefi-sien reliabilitas dari angket motivasi belajar dan akhlak mulia, digunakan formula Alpha Cronbach dengan rumus sebagai berikut:

$r_{x x^{\prime}}=\frac{k}{k-1}\left(1-\frac{\sum s_{i}^{2}}{s_{t}^{2}}\right)$

Keterangan:

$\mathrm{r}_{\mathrm{zx}}{ }^{\mathrm{F}}=$ koefisien reliabilitas instrumen

$\mathrm{K}$ = banyaknya item tes

$s_{i}^{2}=$ varian skor siswa pada suatu item tes

$\mathrm{s}_{\mathrm{t}}^{2}=$ varian skor total

Berdasarkan hasil analisis mengguna-kan SPSS 16 for windows, diperoleh nilai koefisien reliabilitas pada instrumen pretes prestasi belajar 0,828 dan untuk postes 0,768 . Pada instrumen pretes motivasi belajar 0,957 dan postes 0,947 . Pada instrumen pretes akhlak mulia pretes 0,956 dan postes 0,956 .

Data tentang prestasi belajar diperoleh melalui pengukuran dengan instrumen tes yang berbentuk pilihan ganda. Untuk menentukan kriteria hasil pengukurannya digunakan Kriteria Ketuntasan Minimal (KKM) yang ada di MA Ali Maksum. Siswa dikatakan tuntas belajar apabila mencapai nilai minimal 65 untuk skala 100.

Data tentang motivasi belajar diperoleh melalui pengukuran dengan instrumen tes yang berbentuk cheklist dengan skala Likert. Penskoran terhadap motivasi belajar memiliki rentang 30 sampai dengan 150 . Untuk menentukan kriteria hasil pengukurannya digunakan klasifikasi berdasarkan rata-rata ideal (Mi) dan Standar Deviasi ideal (Si).

Rata-rata ideal $=\bar{X}=\frac{(30+150)}{2}=90$

Standar Deviasi Ideal $(S D i)=\frac{150-30}{6}=20$

Tabel 2. Kriteria Motivasi Belajar

\begin{tabular}{|c|c|c|}
\hline Interval & Skor $(X)$ & Kategori \\
\hline$Z+1,5 S D i<Z \leq X I+3 S D i$ & $120<X \leq 150$ & $\begin{array}{l}\text { Sangat } \\
\text { Tinggi }\end{array}$ \\
\hline$Z+0,5 S D i<Z \leq Z+1,5 S D i$ & $100<Z \leq 120$ & Tinggi \\
\hline$Z-0,5 S D i<Z \leq Z+0,5 S D i$ & $80<Z \leq 100$ & Sedang \\
\hline$Z-1,5 \mathrm{SDi}<Z \leq Z-0,5 \mathrm{SDi}$ & $60<X \leq 80$ & Rendah \\
\hline$Z-3 S D i<Z \leq Z-1,5 S D i$ & $30<X \leq 60$ & $\begin{array}{l}\text { Sangat } \\
\text { Rendah }\end{array}$ \\
\hline
\end{tabular}

Data tentang akhlak mulia diperoleh melalui pengukuran dengan instrumen tes yang berbentuk cheklist dengan skala Likert. Penskoran terhadap akhlak mulia memiliki rentang 60 sampai dengan 300. Untuk menentukan kriteria hasil pengukurannya digunakan klasifikasi berdasarkan rata-rata ideal (Mi) dan Standar Deviasi ideal ( $\mathrm{Si})$.

Rata-rata ideal $=\bar{X}=\frac{(60+300)}{2}=180$

Standar Deviasi Ideal $(S D i)=\frac{300-60}{6}=40$

Tabel 3. Kriteria Akhlak Mulia

\begin{tabular}{|c|c|c|}
\hline Interval & Skor $(\mathrm{X})$ & Kategori \\
\hline $\bar{x}+1,5 \operatorname{san}<x<\bar{x}+\operatorname{san}$ & $200<x<300$ & Sangat Tinggi \\
\hline $\bar{x}+0,5 \operatorname{sen}<x<\bar{x}+1, \sin$ & $200<x<260$ & Tinggi \\
\hline $\bar{x}-0,5 \sin <x<\bar{x}+0,5 r 0 s$ & $160<x<200$ & Sedang \\
\hline $\bar{x}-1,5 \operatorname{sen}<x<\bar{x}-0, \sin$ & $120<\times x<160$ & Rendah \\
\hline $\bar{x}-\operatorname{man}<x \leq \bar{x}-1, \sin$ & $60<x<100$ & Sangat Rendah \\
\hline
\end{tabular}

Sebelum dilakukan analisis data, dilakukan uji asumsi terlebih dahulu, yaitu uji normalitas dan homogenitas. Pada uji normalitas digunakan metode Kolmogorov-Smirnov, dan untuk mengetahui homogenitas matriks varians-kovarians dua kelompok dengan tiga variabel dependen secara simultan dilakukan melalui uji homogenitas Box-M dan levene's. Uji normalitas dan homogenitas menggunakan bantuan software SPSS 16.0.

Pengujian hipotesis tahap awal adalah $u j i$ one sample t-test yang bertujuan untuk melihat apakah pendekatan cooperative learning tipe STAD dan tipe Jigsaw efektif ditinjau dari masing-masing variabel yaitu prestasi belajar, motivasi belajar dan akhlak mulia. Kriteria keefektifan menggunakan Kriteria Ketuntasan Minimal (KKM), dimana pada rentang nilai 0 100 memiliki nilai KKM nya 65 . Pada motivasi belajar memiliki rentang 30-150 sehingga krite- 
ria hasil pengukurannya adalah 100 . Pada akhlak mulia memiliki rentang nilai 60 - 300 sehingga kriteria hasil pengukurannya adalah 240. Pembelajaran dikatakan efektif jika rata-rata tes pres-tasi belajar > 65, untuk motivasi belajar jika hasil pengukurannya $>100$, dan untuk akhlak mulia jika hasil pengukurannya $>240$.

Kriteria pengujiannya adalah jika $t_{\text {hit }}>t_{\text {tab }}$ maka tolak $\mathrm{H}_{0}$. Rumus yang digunakan adalah :

$t=\frac{\bar{X}-\mu_{0}}{\frac{s}{\sqrt{n}}}$

Keterangan

$\bar{X}=$ nilai rata-rata

$\mu_{0}=$ nilai yang dihipotesiskan

$\mathrm{s}=$ simpangan baku sampel yang dihitung

$\mathrm{n}=$ jumlah anggota sampel

Uji one sample test dilakukan dengan bantuan program software SPSS versi 16.0. Kriteria tolak $\mathrm{H}_{0}$ jika nilai signifikansi uji t kurang dari 0,05 .

Untuk mengetahui keefektifan masingmasing pendekatan pembelajaran cooperative learning tipe STAD dan tipe Jigsaw ditinjau dari aspek prestasi belajar siswa terhadap matematika maka hipotesis statistiknya sebagai berikut.

1. Kelompok STAD

$$
\begin{aligned}
& \mathrm{H}_{0}: \mu_{11} \leq 65 \\
& \mathrm{H}_{\mathrm{a}}: \mu_{11}>65
\end{aligned}
$$

2. Kelompok Jigsaw

$$
\begin{aligned}
& \mathrm{H}_{0}: \mu_{11} \leq 65 \\
& \mathrm{H}_{\mathrm{a}}: \mu_{12}>65
\end{aligned}
$$

Untuk mengetahui keefektifan masingmasing pendekatan pembelajaran ditinjau dari aspek motivasi belajar, maka hipotesis statisticnya sebagai berikut.

1. Kelompok STAD

$$
\begin{aligned}
& \mathrm{H}_{0}: \mu_{21} \leq 100 \\
& \mathrm{H}_{\mathrm{a}}: \mu_{21}>100
\end{aligned}
$$

2. Kelompok Jigsaw

$$
\begin{aligned}
& \mathrm{H}_{0}: \mu_{22} \leq 100 \\
& \mathrm{H}_{\mathrm{a}}: \mu_{22}>100
\end{aligned}
$$

Sedangkan untuk mengetahui keefektifan masing-masing pendekatan pembelajaran ditinjau dari aspek akhlak mulia digunakan hipotesis statistik sebagai berikut.

1. Kelompok STAD

$\mathrm{H}_{0}: \mu_{32} \leq 240$

Ha $: \mu 31>240$

2. Kelompok Jigsaw

$\mathrm{H}_{0}: \mu_{32} \leq 65$
Langkah selanjutnya adalah melakukan uji multivariat atau MANOVA. Uji multivariat bertujuan untuk melihat adanya perbedaan keefektifan terhadap kedua kelompok, apakah kedua kelompok tersebut berbeda secara signifikan ditinjau dari ketiga variabel tersebut. Perhitungan uji multivariat dilakukan dengan menggunakan statistik uji $T^{2}$ Hotelling dan uji $F$ yang dirumuskan oleh Stevens (2002, p.176) sebagai berikut:

$T^{2}=\frac{n_{1} n_{2}}{n_{1}+n_{2}}\left(\overline{y_{1}}-\overline{y_{2}}\right) S^{-1}\left(\overline{y_{1}}-\overline{y_{2}}\right)$

Keterangan:

$T^{2}=$ Hotteling trace

$n_{1}=$ besar sampel dari kelompok I

$n_{2}=$ besar sampel dari kelompok II

$\overline{y_{1}}=$ vektor rerata skor sampel I

$\overline{y_{2}}=$ vektor rerata skor sampel II

$S=$ matriks dispersi

Selanjutnya dilakukan uji $F$ dengan menggunakan rumus:

$F=\frac{\left(n_{1}+n_{2}-p-1\right)}{\left(n_{1}+n_{2}-2\right) p} T^{2}$

Kriteria pengujiannya adalah $\mathrm{H}_{0}$ ditolak jika $F_{\text {hitung }}$ lebih dari $F\left(p ; n_{1}+n_{2}-p-1 ; 0,05\right)$ atau angka signifikansi yang dihasilkan lebih kecil dari 0,05. Pengujian ini dilakukan dengan menggunakan bantuan SPSS windows versi 16.0. Adapun hipotesis secara statistik, dapat disimbolkan sebagai berikut:

$\mathrm{H}_{0}:\left(\begin{array}{l}\mu_{11} \\ \mu_{21} \\ \mu_{31}\end{array}\right)=\left(\begin{array}{l}\mu_{12} \\ \mu_{22} \\ \mu_{32}\end{array}\right)$,
$\mathrm{H}_{\mathrm{a}}:\left(\begin{array}{l}\mu_{11} \\ \mu_{21} \\ \mu_{31}\end{array}\right) \neq\left(\begin{array}{l}\mu_{12} \\ \mu_{22} \\ \mu_{32}\end{array}\right)$

Dimana $\mu_{11}$ menyatakan rerata dari prestasi belajar dengan pendekatan cooperative learning tipe STAD, sedangkan $\mu_{12}$ adalah rerata dari prestasi belajar dengan pendekatan cooperative learning tipe Jigsaw. $\mu_{21}$ adalah rerata dari motivasi belajar dengan pendekatan cooperative learning tipe STAD, sedangkan $\mu_{22}$ adalah rerata dari motivasi belajar dengan pendekatan cooperative learning tipe Jigsaw. Sedangkan $\mu_{31}$ adalah rerata dari akhlak mulia dengan pendekatan cooperative learning tipe STAD, sedangkan $\mu_{32}$ adalah rerata dari akhlak mulia dengan pendekatan cooperative learning tipe Jigsaw. 
Pengujian hipotesis selanjutnya adalah uji independent samples t-test. Pengujian ini dapat dilakukan jika terdapat perbedaan keefektifan pendekatan cooperative learning tipe STAD dengan cooperative learning tipe Jigsaw. Uji independent samples t-test bertujuan untuk menyelidiki apakah pembelajaran matematika dengan pendekatan cooperative learning tipe STAD lebih efektif dari pembelajaran matematika dengan pendekatan cooperative learning tipe Jigsaw ditinjau dari masing-masing variabel yaitu prestasi belajar, motivasi belajar dan akhlak mulia. Kriteria yang digunakan adalah kriteria Bonferroni dimana taraf siginfikansinya adalah $\alpha / p$, jadi untuk untuk $\alpha=0,05$ maka untuk masing-masing uji $t$ digunakan kriteria $0,05 / 3=0,017$ (Stevens, 2002, p.181). Kriteria pengujian $t_{\text {hit }}>t_{\text {tab }}$ maka tolak $H_{0}$. Rumus uji Univariat yang digunakan menurut Stevens (2002, p.176) adalah:

$$
t=\frac{\overline{y_{1}}-\overline{y_{2}}}{\sqrt{\frac{\left(n_{1}-1\right) s_{1}^{2}+\left(n_{2}-1\right) s_{2}^{2}}{n_{1}+n_{2}-2}\left(\frac{1}{n_{1}}+\frac{1}{n_{2}}\right)}}
$$

Keterangan

$\overline{y_{1}}=$ rata-rata kelompok I

$\overline{y_{2}}=$ rata-rata kelompok II

$s_{1}^{2}=$ varians kelompok I

$s_{2}^{2}=$ varians kelompok II

$\mathrm{n}_{1}=$ besar sampel dari kelompok I

$\mathrm{n}_{2}=$ besar sampel dari kelompok II

Hipotesis yang diuji untuk $t$-test adalah:

1. $\mathrm{H}_{0}: \mu_{11}=\mu_{12}$

$\mathrm{H}_{\mathrm{a}}: \mu_{11} \neq \mu_{12}$

2. $\mathrm{H}_{0}: \mu_{21}=\mu_{22}$

$$
\mathrm{H}_{\mathrm{a}}: \mu_{21} \neq \mu_{22}
$$

3. $\mathrm{H}_{0}: \mu_{31}=\mu_{32}$

$$
\mathrm{H}_{\mathrm{a}}: \mu_{31} \neq \mu_{32}
$$

Perhitungan untuk menguji hipotesis ini dengan menggunakan Independent-samples $T$ test dengan menggunakan SPSS versi 16.0. Adapun kriteria pengujian tolak $\mathrm{H}_{0}$ jika nilai sign uji t memiliki nilai signifikansi yang lebih kecil dari 0,05 .

\section{HASIL DAN PEMBAHASAN}

Data tes prestasi belajar yang dideskripsikan terdiri atas data pretes dan data postes. Secara ringkas, hasil tes prestasi belajar siswa pada kedua kelompok disajikan dalam Tabel 4.
Tabel 4. Deskripsi Hasil Tes Prestasi Belajar

\begin{tabular}{lcccc}
\hline & \multicolumn{2}{c}{ Jigsaw } & \multicolumn{2}{c}{ STAD } \\
\cline { 2 - 5 } & Pre & Post & Pre & Post \\
\hline Rata-rata & 5,68 & 23,5 & 4,73 & 24,43 \\
Standar deviasi & 2,65 & 3,36 & 3,19 & 3,26 \\
Skor maksimum & 30 & 30 & 30 & 30 \\
teoretik & 0 & 0 & 0 & 0 \\
Skor minimum teoretik & 9 & 29 & 13 & 29 \\
Skor maksimum & 1 & 14 & 1 & 14 \\
Skor minimum & & &
\end{tabular}

Sedangkan untuk mengetahui motivasi belajar matematika siswa maka kedua kelompok siswa diberikan angket motivasi belajar matematika sebelum dan sesudah pemberian treatment. Ringkasan hasil angket disajikan pada Tabel 5.

Tabel 5. Deskripsi Hasil Angket Motivasi Belajar Matematika

\begin{tabular}{lcccc}
\hline & \multicolumn{2}{c}{ Jigsaw } & \multicolumn{2}{c}{ STAD } \\
\cline { 2 - 5 } & Pre & Post & Pre & Post \\
\hline Rata-rata & 89,32 & 118,9 & 87,4 & 117,2 \\
Standar deviasi & 20,2 & 9,81 & 15,15 & 12,94 \\
Skor maks. Teoretik & 150 & 150 & 150 & 150 \\
Skor min. teoretik & 0 & 0 & 0 & 0 \\
Skor maksimum & 134 & 141 & 111 & 141 \\
Skor minimum & 63 & 95 & 66 & 86 \\
\hline
\end{tabular}

Frekuensi dan persentase banyak siswa pada setiap kriteria motivasi belajar dihitung sesuai dengan rentang skor yang telah ditentukan. Distribusi frekuensi dan presentasi motivasi belajar sebelum dan setelah treatment disajikan pada Tabel 6 dan Tabel 7.

Tabel 6. Distribusi Frekuensi Motivasi Belajar Sebelum Treatment

\begin{tabular}{cccccc}
\hline \multirow{2}{*}{ Skor $(X)$} & \multirow{2}{*}{ Kriteria } & \multicolumn{2}{c}{ Jigsaw } & \multicolumn{2}{c}{ STAD } \\
\cline { 3 - 6 } & & $\mathbf{F}$ & $\mathbf{\%}$ & $\mathbf{F}$ & $\%$ \\
\hline $120<\mathrm{X}=150$ & Sangat & 2 & 7,14 & 0 & 0 \\
& Tinggi & & & & \\
$100<\mathrm{X}=120$ & Tingggi & 6 & 21,43 & 8 & 26,67 \\
$80<\mathrm{X}=100$ & Sedang & 7 & 25 & 11 & 36,67 \\
$60<\mathrm{X}=80$ & Rendah & 13 & 46,43 & 11 & 36,67 \\
$30<\mathrm{X}=60$ & Sangat & 0 & 0 & 0 & 0 \\
& Rendah & & & &
\end{tabular}

\begin{tabular}{|c|c|c|c|c|c|}
\hline \multirow{2}{*}{ Skor $(\mathbf{X})$} & \multirow{2}{*}{ Kriteria } & \multicolumn{2}{|c|}{ Jigsaw } & \multicolumn{2}{|c|}{ STAD } \\
\hline & & $\mathbf{F}$ & $\%$ & $\mathbf{F}$ & $\%$ \\
\hline $120<X<150$ & $\begin{array}{c}\text { Sangat } \\
\text { tinggi }\end{array}$ & 12 & 42,86 & 14 & 46,67 \\
\hline $100<\mathrm{X}=120$ & Tinggi & 14 & 50 & 12 & 40 \\
\hline $80<X \leq 100$ & Sedang & 2 & 7,14 & 4 & 13,33 \\
\hline $60<X \leq 80$ & Rendah & 0 & 0 & 0 & 0 \\
\hline $30 \leq X \leq 60$ & $\begin{array}{l}\text { Sangat } \\
\text { rendah }\end{array}$ & 0 & 0 & 0 & 0 \\
\hline
\end{tabular}

Tabel 7. Distribusi Frekuensi Motivasi Belajar Setelah Treatment 
Untuk mengetahui akhlak mulia siswa maka kedua kelompok siswa diberikan angket akhlak mulia sebelum dan sesudah pemberian treatment. Ringkasan hasil angket disajikan pada Tabel 8.

Tabel 8. Deskripsi Hasil Angket Akhlak Mulia Siswa

\begin{tabular}{lcccc}
\hline & \multicolumn{2}{c}{ Jigsaw } & \multicolumn{2}{c}{ STAD } \\
\cline { 2 - 5 } & Pre & Post & Pre & Post \\
\hline Rata-rata & 232,7 & 266,3 & 235,5 & 267,4 \\
Standar deviasi & 23,86 & 13,3 & 20,95 & 16,81 \\
Skor maks. teoretik & 300 & 300 & 300 & 300 \\
Skor mini. teoretik & 0 & 0 & 0 & 0 \\
Skor maksimum & 261 & 290 & 264 & 293 \\
Skor minimum & 186 & 238 & 198 & 231 \\
\hline
\end{tabular}

Frekuensi dan persentase banyak siswa pada setiap kriteria akhlak mulia dihitung sesuai dengan rentang skor yang telah ditentukan. Distribusi frekuensi dan presentasi akhlak mulia sebelum dan setelah treatment disajikan pada Tabel 9 dan Tabel 10.

Tabel 9. Distribusi Frekuensi Akhlak Mulia Sebelum Treatment

\begin{tabular}{cccccc}
\hline \multirow{2}{*}{ Skor $(\mathbf{X})$} & \multirow{2}{*}{ Kriteria } & \multicolumn{2}{c}{ Jigsaw } & \multicolumn{2}{c}{ STAD } \\
\cline { 3 - 6 } & & $\mathbf{F}$ & $\mathbf{\%}$ & $\mathbf{F}$ & $\%$ \\
\hline $240<\mathrm{X}=300$ & Sangat & 13 & 46,43 & 16 & 53,33 \\
& Tinggi & & & \\
$200<\mathrm{X}<240$ & Tingggi & 12 & 42,86 & 12 & 40 \\
$160<\mathrm{X}=200$ & Sedang & 3 & 10,71 & 2 & 6,67 \\
$120<\mathrm{X}=160$ & Rendah & 0 & 0 & 0 & 0 \\
$60<\mathrm{X}=120$ & Sangat & 0 & 0 & 0 & 0 \\
& Rendah & & & & \\
\hline
\end{tabular}

Tabel 10. Distribusi Frekuensi Akhlak Mulia Setelah Treatment

\begin{tabular}{cccccc}
\hline \multirow{2}{*}{ Skor $(\mathbf{X})$} & \multirow{2}{*}{ Kriteria } & \multicolumn{2}{c}{ Jigsaw } & \multicolumn{2}{c}{ STAD } \\
\cline { 3 - 6 } & F & \% & F & \% \\
\hline $240<\mathrm{X}=300$ & $\begin{array}{c}\text { Sangat } \\
\text { tinggi }\end{array}$ & 27 & 96,43 & 29 & 96,67 \\
$200<\mathrm{X}=240$ & Tinggi & 1 & 3,57 & 1 & 3,33 \\
$160<\mathrm{X}=200$ & Sedang & 0 & 0 & 0 & 0 \\
$120<\mathrm{X}=160$ & Rendah & 0 & 0 & 0 & 0 \\
$60<\mathrm{X}=120$ & $\begin{array}{c}\text { Sangat } \\
\text { rendah }\end{array}$ & 0 & 0 & 0 & 0 \\
\hline
\end{tabular}

Analisis data yang digunakan dalam penelitian ini adalah analisis statistik inferensial yang merupakan analisis statistik yang diguna-kan untuk mengambil keputusan berdasarkan data yang telah diperoleh. Data yang dianalisis pada analisis statistik inferensial adalah data yang diperoleh sebelum maupun setelah treatment.
Tabel 11. Hasil Uji Normalitas Data

\begin{tabular}{ccccc}
\multirow{2}{*}{ Variabel } & \multicolumn{2}{c}{$\begin{array}{c}\text { Sebelum } \\
\text { treatment }\end{array}$} & \multicolumn{2}{c}{$\begin{array}{c}\text { Setelah } \\
\text { treatment }\end{array}$} \\
\cline { 2 - 5 } & $\boldsymbol{K} \boldsymbol{S}$ & Sig & $\boldsymbol{K}-\boldsymbol{S}$ & Sig \\
\hline Prestasi belajar & 1,069 & 0,203 & 0,723 & 0,624 \\
& 0,752 & 0,624 & 0,988 & 0,283 \\
Motivasi Belajar & 0,895 & 0,399 & 1,161 & 0,135 \\
& 1,161 & 0,135 & 1,042 & 0,227 \\
Akhlak Mulia & 0,961 & 0,314 & 0,746 & 0,633 \\
& 0,746 & 0,633 & 0,702 & 0,708 \\
\hline
\end{tabular}

Tabel 12. Hasil Uji Homogenitas Multivariat

\begin{tabular}{ccc}
\hline & Sebelum & Setelah \\
\hline Box's M & 14,072 & 4,486 \\
F & 2,208 & 0,704 \\
df1 & 6 & 6 \\
df2 & $3,241 \mathrm{E} 4$ & $2,241 \mathrm{E} 4$ \\
Signifikansi & 0,039 & 0,646 \\
\hline
\end{tabular}

Tabel 13. Hasil Uji Homogenitas Univariat Data Sebelum Treatment

\begin{tabular}{ccccc}
\hline Variabel & F & df1 & df2 & Sig. \\
\hline Prestasi Belajar & 0,159 & 1 & 56 & 0,692 \\
Motivasi Belajar & 3,751 & 1 & 56 & 0,058 \\
Akhlak Mulia & 0,557 & 1 & 56 & 0,458
\end{tabular}

Tabel 14. Hasil Uji Homogenitas Univariat Data Setelah Treatmen

\begin{tabular}{ccccc}
\hline Variabel & F & df1 & df2 & Sig. \\
\hline Prestasi Belajar & 0,455 & 1 & 56 & 0,503 \\
Motivasi Belajar & 2,547 & 1 & 56 & 0,116 \\
Akhlak Mulia & 2,020 & 1 & 56 & 0,161 \\
\hline
\end{tabular}

Tabel 15. Hasil Uji One-sample t-test

\begin{tabular}{lcccc}
\hline & t & df & Sig. (2-tailed) \\
\hline Prestasi belajar & 1 & 6,093 & 27 & 0,000 \\
Prestasi belajar & 2 & 8,074 & 29 & 0,000 \\
Motivasi belajar & 1 & 10,207 & 27 & 0,000 \\
Motivasi belajar & 2 & 7,292 & 29 & 0,000 \\
Akhlak mulia & 1 & 26,379 & 27 & 0,000 \\
Akhlak mulia & 2 & 21,960 & 29 & 0,000 \\
\hline
\end{tabular}

Penerapan pendekatan pembelajaran bertujuan untuk memperbaiki proses pembelajaran yang terjadi dalam kelas dan diharapkan berimplikasi baik pada hasil yang akan dicapai. Tidak efektifnya pembelajaran yang terjadi maka bisa dikatakan bahwa pendekatan pembelajaran yang diterapkan tersebut tidak efektif pada tujuan pembelajaran yang telah ditetapkan. Sebelum melihat pengaruh dan membandingkan kedua tipe pendekatan cooperative leaning tersebut, yang perlu diperhatikan lebih awal adalah keefektifannya.

Keefektifan pendekatan cooperative learning tipe STAD dan Jigsaw ditinjau dari prestasi belajar, motivasi belajar, dan akhlak 
mulia siswa kelas X MA Ali Maksum Krapyak Yogyakarta, dapat dilihat dari kriteria ketuntasan minimal (KKM) yang telah ditentu-kan untuk masing-masing variabel dependen. KKM yang telah ditentukan untuk prestasi belajar siswa dikatakan berhasil apabila mencapai skor lebih dari 65, sedangkan untuk motivasi belajar siswa dikatakan berhasil apabila mendapat jumlah skor lebih dari 90, dan untuk akhlak mulia siswa dikatakan berhasil jika mendapat jumlah skor lebih dari 180.

Penerapan pendekatan cooperative learning tipe STAD, berdasarkan kriteria keputusan pada $t$-test one sample efektif ditinjau dari prestasi belajar, motivasi belajar, dan akhlak mulia siswa. Hal ini disebabkan karena dalam proses pembelajaran matematika siswa berpartisipasi aktif melalui diskusi dengan anggota-anggota kelompoknya. Selain itu, siswa diberikan penghargaan sehingga siswa menjadi senang dan terpacu untuk belajar, dan menjadi lebih baik dari sebelumnya. Hal inilah yang menyebabkan pendekatan cooperative learning tipe STAD efektif ditinjau dari prestasi belajar, motivasi belajar, dan akhlak mulia siswa.

Cooperative learning tipe STAD efektif ditinjau dari prestasi belajar, motivasi belajar, dan akhlak mulia siswa sejalan dengan kajian teori dan hasil penelitian, Arends (1997, p.119) yang mengemukakan bahwa STAD merupakan pendekatan pembelajaran kooperatif yang paling sederhana dan paling mudah diterapkan oleh guru yang baru menggunakan pendekatan pembelajaran kooperatif. Slavin $(2005$, p.6) mengemukakan bahwa "the main idea behind student Teams-Achevement Divisions is to motivate student to encourage and help other masterskills presented by teacher". Berdasarkan pendapat tersebut dapat diketahui bahwa gagasan utama dari STAD adalah untuk memotivasi siswa supaya dapat saling mendukung dan membantu satu sama lain dalam menguasai kemampuan yang diajarkan oleh guru.

Penerapan pendekatan cooperative learning tipe Jigsaw, berdasarkan kriteria keputusan pada $t$-test one sample, efektif ditinjau dari prestasi belajar, motivasi belajar, dan akhlak mulia siswa. Hal ini disebabkan karena dalam proses pembelajaran matematika siswa berpartisipasi aktif melalui diskusi dengan anggota-anggota kelompok ahli dan kelompok asalnya. Selain itu, siswa diberikan penghargaan sehingga siswa menjadi senang dan terpacu untuk belajar, dan menjadi lebih baik dari sebelumnya. Hal inilah yang menyebabkan pendekatan cooperative learning tipe Jigsaw efektif ditinjau dari prestasi belajar, motivasi belajar, dan akhlak mulia siswa.

Cooperative learning tipe Jigsaw efktif ditinjau dari prestasi belajar, motivasi belajar, dan akhlak mulia siswa, sejalan dengan kajian teori dan hasil penelitian Arends (2008, p.13) bahwa model pembelajaran kooperatif tipe Jigsaw merupakan salah satu tipe pembelajaran kooperatif yang mendorong siswa aktif dan saling membantu dalam menguasai materi pelajaran untuk mencapai prestasi yang maksimal. Selanjutnya Slavin (2005, p.6) mengemukakan bahwa "in it, student work in the same four member heterogeneous teams as in STAD and TGT".

Dari uraian tersebut diketahui bahwa pendekatan cooperative learning tipe STAD maupun Jigsaw efektif ditinjau dari prestasi belajar, motivasi belajar, dan akhlak mulia siswa. Selain itu, diketahui pula kondisi awal dari kedua kelompok eksperimen berdistribusi normal dan homogen. Dengan mengacu pada tujuan penelitian yaitu untuk mendeskripsikan pendekatan cooperative learning manakah yang lebih efektif antara tipe STAD dan Jigsaw ditinjau dari prestasi belajar, motivasi belajar, dan akhlak mulia siswa, dan untuk dapat memberikan rekomendasi mengenai penerapan dua pendekatan cooperative learning tipe STAD dan Jigsaw, maka perlu diuji pendekatan mana yang lebih efektif. Untuk dapat mengetahui pendekatan pembelajaran mana yang lebih efektif, maka dilakukan komparasi.

Tabel 16. Uji MANOVA

\begin{tabular}{lll}
\hline & F & Sig \\
\hline Kelas (sebelum perlakuan) & $2,133^{\mathrm{a}}$ & 0,107 \\
Kelas (setelah perlakuan) & $0,679^{\mathrm{a}}$ & 0,569 \\
\hline
\end{tabular}

Berdasarkan hasil analisis multivariat dengan two-group MANOVA, $H_{0}$ dalam penelitian ini diterima. Hal ini menunjukkan bahwa hipotesis penelitian yang menyatakan terdapat perbedaan yang signifikan antara pendekatan cooperative learning tipe STAD dan Jigsaw ditinjau dari prestasi belajar, motivasi belajar, dan akhlak mulia siswa ditolak. Berdasarkan hasil tersebut dapat disimpulkan bahwa tidak terdapat perbedaan yang signifikan antara pendekatan cooperative learning tipe STAD dan Jigsaw ditinjau dari prestasi belajar, motivasi belajar, dan akhlak mulia siswa.

Tidak terdapatnya perbedaan antara pendekatan cooperative learning tipe STAD dan Jigsaw karena masing-masing tipe tersebut 
mempunyai kelebihan tersendiri, STAD dalam proses pembelajaran matematika memacu siswa untuk berpartisipasi aktif melalui diskusi dengan anggota-anggota kelompoknya, serta diberikan penghargaan sehingga siswa menjadi senang dan terpacu untuk belajar, dan menjadi lebih baik dari sebelumnya, sedangkan Jigsaw membuat siswa berpartisipasi aktif melalui diskusi dengan anggota-anggota kelompok ahli, kelompok asalnya, dan diberikan penghargaan sehingga siswa menjadi senang dan terpacu untuk belajar dan menjadi lebih baik dari sebelumnya. Berdasarkan perbadingan tipe pembelajaran kooperatif menurut Arends (2008) antara tipe STAD dan Jigsaw secara umum mempunyai kesamaan dilihat dari tujuan kognitif, tujuan sosial, struktur kelompok, pemilihan topik pelajaran, asesmen, dan rekognisi.

Walaupun tidak terdapat perbedaan keefektifan antara pendekatan cooperative learning tipe STAD dan cooperative learning tipe Jigsaw, keduanya efektif dalam pembelajaran matematika khususnya pada materi trigonometri. Efektif yang dimaksud adalah efektif ditinjau dari prestasi belajar, motivasi belajar, dan akhlak mulia siswa. Dengan demikian, baik STAD maupun Jigsaw sebagai tipe pada pendekatan cooperative learning dan keduanya mampu meningkatkan prestasi belajar, motivasi belajar, dan akhlak mulia siswa. Hal ini sesuai dengan pernyataan Slavin $(2005$, p.2) yang mengemukakan bahwa alasan penggunaan cooperative learning adalah untuk dapat meningkatkan kemampuan menyelesaikan soal.

\section{SIMPULAN DAN SARAN}

\section{Simpulan}

Berdasarkan hasil analisis data dan pembahasan, dapat disimpulkan bahwa pendekatan cooperative learning tipe STAD dan Pendekatan cooperative learning tipe Jigsaw efektif ditinjau dari prestasi belajar, motivasi belajar, dan akhlak mulia siswa kelas X MA Ali Maksum Krapyak Yogyakarta dan tidak terdapat perbedaan keefektifan pendekatan cooperative learning tipe STAD dan pendekatan cooperative learning tipe Jigsaw ditinjau dari prestasi belajar, motivasi belajar, dan akhlak mulia siswa kelas X MA Ali Maksum Krapyak Yogyakarta.

\section{Saran}

Berdasarkan hasil dan uraian sebelumnya, maka dapat dibuat suatu rekomendasi bahwa untuk meningkatkan prestasi belajar, motivasi belajar, dan akhlak mulia siswa, guru dapat melakukan inovasi pembelajaran dengan menerapkan pendekatan pembelajaran yang berpusat pada siswa yaitu menerapkan pendekatan cooperative learning tipe STAD dan Jigsaw. Disarankan kepada peneliti selanjutnya agar memperluas materi yang digunakan dalam penelitian, sehingga memungkinkan generalisasi yang lebih luas.

\section{DAFTAR PUSTAKA}

Al-Qasimi, M. J. (1998). Mau'idhatul mu'minin. Beirut: Darul Fikri.

Arends, R. I. (1997). Clasroom instruction and management. New York,: The McGrawHill Companies.

Arends, R. I. (2008). Learning to teach. New York: The McGraw-Hill Companies.

Arends, R. I., \& Kilcher, A. (2010). Teacing for student learning: Becoming an accomplished teacher. New York: Routledge Published.

Begle, E. G. (1979). Critical variables in mathematics education. Washington, DC: The Mathematical Assosiation of American.

Borich, G. D. (2007). Efective teaching methods. $\left(6^{\text {th }}\right.$ ed.). Upper Saddle River, NJ: Merril Prentice-Hall.

Cohen, J. (2006). Social, emotional, ethnical and academic education: Creating climate for learning, participation in democracy and well being. Harvard Education Riview, 71(2), 201-237.

Depdiknas. (2005). Peraturan Pemerintah RI Nomor 19, Tahun 2005, tentang Standar Nasional Pendidikan.

Ebel, R. I, \& Frisbie, D. A. (1986). Essential of educational mesurement $\left(4^{\text {th }}\right.$ ed). Upper Saddle River, NJ: Prentice-Hell, Inc.

Fahrurrozi, F., \& Mahmudi, A. (2014). Pengaruh PBM dalam setting pembelajaran kooperatif tipe STAD dan GI terhadap prestasi belajar dan kecerdasan emosional siswa. Jurnal Riset Pendidikan Matematika, 1(1), 1-11. doi:http://dx.doi.org/10.21831/jrpm.v1i1. $\underline{2653}$

Huitt, G. W. (2001). Educational psychology interactive: Motivation to learn. Diakses pada 10 Oktober 2012 dari http://www.edpsycinteractive.org/topics/motivation/motivate.html 
Harian Kompas. (2011). Prevalensi penyalahgunaan narkoba di Indonesia.

Johnson, D. W., \& Johnson, R. T. (2002). Meaningful assessment: A manageable and cooperative proses. Boston, MA: Allyn and Bacon.

Lickona, T. (1991). Educting for character: How our schools can teach respect and responsibility. New York, NY: Bantam Books.

Mendiknas. (2007) Peraturan Menteri Pendidikan Nasional Nomor 41 Tahun 2007, tentang Standar Proses.

Moore, L. L., Grabsch, D. K., Rotter, C. (2010). Using achievement motivation theory to explain student participation in a residential leadership learning community. Journal of Leadership Education, 9(1), 22-34.

Musfiroh, T. (2008). Cerdas melalui bermain. Jakarta: PT Grasindo

Musfiroh, T. (2008). Pengembangan karakter anak melalui pendidikan karakter. Dalam buku Tinjauan Berbagai Aspek Character Building, Penyunting Aris-mantoro. Yogyakarta: Lemlit UNY dan Penerbit Tiara Wacana.

Persky, A. M. \& Pollack, G. M. (2009). Instructional design and assessment: a hybrid jigsaw approach to teaching renal clearance concepts. American Journal of Pharmaceutical Education, 73 (3), 1-12.

Presiden Republik Indonesia. (2003). Peraturan Pemerintah RI Nomor 20, Tahun 2003, tentang Sistem Pendidikan Indonesia.

Robbins, S.P., \& Judge, T. A. (2009). Organizational behaviour. Upper Saddle River, NJ: Pearson Educational.

Romberg, T.A., \& Shafer, M.C. (2008). The impact of reform instruction on student mathematics achievement. New York, NY: Routledge.

Sanjaya, W. (2006). Strategi pembelajaran berorientasi proses standar proses pendidikan. Jakarta: Kencana Prima

Santrock, J. W. (2008). Psikologi pendidikan. (Terjemahan Tri Wibowo). Boston, MA: McGraw-Hill. Buku asli terbit tahun 2008.
Sardiman, A. M. (2001). Interaksi dan motivasi belajar mengajar pedoman bagi guru dan calon guru. Jakarta: Raja Grafindo Persada.

Schunk, D. H, Pintrich, P. R \& Meece, J. L. (2010). Motivation in education theory, research, and applications $\left(3^{\text {rd }} e d\right.$.). New York, NY: Pearson Educational.

Slavin, R. E. .(2008). Cooperative learning: Teori, riset, dan praktik. (Terjemahan Zubaedi). Boston, MA: Allyn \& Bacon. Buku asli terbit tahun 2005.

Slavin, R. E. (2005). Cooperative learning: Theory, research and practice. Boston, MA: Allyn \& Bacon.

Slavin, R.E. (1994). Educational psychology theory: Theory and practice $\left(4^{\text {th }} E d\right.$.). Boston, MA: Allyn \& Bacon.

Suratno, S. (2014). Keefektifan pembelajaran tipe TPS dan JIGSAW ditinjau dari prestasi belajar matematika dan karakter siswa. PYTHAGORAS: Jurnal Pendidikan Matematika, $\quad 9(1), \quad 70-78$. doi:http://dx.doi.org/10.21831/pg.v9i1.90 $\underline{69}$

Tercanlioglu, L. (2004). Achievement goal theory: A perspective on foreignlanguage-learners' motivation. Tesl Canada Journal, 2(2), 34-49.

Wahyuni, A., \& Abadi, A. (2014). Perbandingan keefektifan pembelajaran cooperative learning type STAD dan type TPS pada pembelajaran bangun ruang siswa SMP. Jurnal Riset Pendidikan Matematika, 1(2), $\quad$ 164-175. doi:http://dx.doi.org/10.21831/jrpm.v1i2. $\underline{2673}$

Winkel, W. S. (1996). Psikologi pengajaran. Jakarta: Gramedia.

Woolfolk, A. (2004). Educational psychology $\left(10^{\text {th }} \mathrm{ed}\right.$.). New York: Pearson Education.

Ilyas, Y. (2006). Kuliah akhlak. Yogyakarta: LPPI UMY

Yunus, A. S., \& Wan, A. W. Z. (2009). Motivation in the learning of mathematics. European Journal of Social Sciences, 7(4), 93-101.

Zuriah, N. (2007). Pendidikan moral dan budi pekerti dalam persfektif perubahan. Jakarta: Bumi Aksara. 